\title{
Investigations on purse seine operations off central Kerala during late 1990s and recent technological changes
}

\author{
A. V. SHIBU, P. M. VIPIN*AND M. SHAHUL HAMEED \\ School of Industrial Fisheries, Cochin University of Science and Technology, Fine Arts Avenue, Kochi - 682 016, India \\ *Central Institute of Fisheries Nautical and Engineering Training, Diwan's Road, Kochi - 682 016, India \\ e-mail: vipinpm83@gmail.com
}

\begin{abstract}
Purse seining is one of the important fishing methods for pelagic fishery resources. The results of investigations on mechanised purse seine operations during late 1990s off central Kerala are presented in this paper along with recent technological changes in the sector. Since its introduction in commercial fisheries, several changes and improvements have taken place in the design and operation of purse seines. The dimensions of the gear which was about 320x $28 \mathrm{~m}$ during early $1970 \mathrm{~s}$, increased to $823 \times 73 \mathrm{~m}$ during late $1990 \mathrm{~s}$ and further to $1200 \times 100 \mathrm{~m}$ towards 2015 . Mesh sizes used in the main body of the seine which were $12-13 \mathrm{~mm}$ during the early days of introduction of the gear, increased to $20-46 \mathrm{~mm}$ in recent years. There was an upward shift in vessel sizes which reached up to $22 \mathrm{~m} \mathrm{~L}_{\mathrm{OA}}$ in recent years, with a significant escalation in installed engine horsepower to $285-510 \mathrm{hp}$. Mechanised purse seine vessels started using fish finding equipment, navigational and communication facilities like Echosounder, global positioning system (GPS) and very high frequency (VHF) radio, in recent years. The role of technological skill of skipper and crew are very important in ensuring the success of purse seining operation and there is a need for technological facilitation in terms of the use of fish finding equipments like sonar, potential fishing zone (PFZ) information based on satellite based remote sensing, possible use of fish aggregating devices and adoption of gear handling equipment such as power blocks.
\end{abstract}

Keywords: Cochin, Kerala, Purse seine, Technological changes

Purse seining is one of the capital and labour intensive fishing practices used for bulk catching of pelagic fishery resources. Purse seining experiments were conducted in India by the erstwhile Indo-Norwegian Project (INP) as early as 1954 (Oommen, 1989) and operations in the commercial small-scale mechanised sector started in 1974, with the technical assistance of INP (Mukundan and Hakkim, 1980). In 2012, about 60 mechanised purse seiners were operating from Kerala (CMFRI, 2012), most of them based at Cochin Fisheries Harbour. The fishing season is from September to May and there is a three month ban on purse seine operation starting from June to August. The main landings include Indian oilsardine (Sardinella longiceps), Indian mackerel (Rastrelliger kanagurta), tunas, carangids, pomfrets, horse mackerel, barracudas, seerfishes and other pelagic species. The success of purse seine operation depends on conditions prevailing during the periods of setting and hauling such as the direction of wind and water currents, speed of encircling, shoal characteristics and knowledge of fish behaviour. In this paper, results of investigations on mechanised purse seiners which were in operation during 1990s off Cochin are presented, along with recent structural and operational changes and emerging technological requirements in the sector.
The data regarding total number of purse seiners operating off Cochin, central Kerala were collected from the records of Cochin Fisheries Harbour authorities. Details of fishing craft and gear were collected by direct enquiry and discussion with fishermen and boat owners, using structured questionnaires and operational details were collected at an interval of 10 days from January to December 1997. Purse seiners were classified into four different length classes based on the length overall $\left(\mathrm{L}_{\mathrm{OA}}\right)$ viz., 14.02-15.24, 15.25-16.76, 16.76-18.29 and $18.30-19.81 \mathrm{~m}$ and $20 \%$ of purse seiners from the different length classes were drawn randomly, for the study.

Information on recent changes in purse seine vessels, gear, engine and operation were collected from fishermen and net makers during a survey conducted from March 2008 to May 2015, at Cochin and Munambam. Secondary data were collected by interaction with fishermen as a part of regular fishermen training programmes conducted by Central Institute of Fisheries Nautical and Engineering Training (2008-2015) and also from state departments, fishermen cooperative societies and log books maintained onboard fishing vessels and from recent studies (Boopendranath, 2000; Meenakumari et al., 2010; 
Renju et al., 2014; Edwin et al., 2014 a,b; Pravin and Meenakumari, 2016).

Purse seiners operated along the Cochin waters during the period 1997-98, were of wooden or steel construction having $\mathrm{L}_{\mathrm{OA}}$ ranging from 14.02 to $19.81 \mathrm{~m}$ with installed engine power from 90 to $160 \mathrm{hp}$, which constituted $83 \%$ of the total fleet. Purse seine vessels used wooden skiffs during encircling operations with $\mathrm{L}_{\mathrm{OA}}$ ranging from 3.05 to $3.66 \mathrm{~m}$. Purse seines were operated from Cochin throughout the year, barring three months from June to August, during which period their operations have been banned under provisions of Kerala Marine Fisheries Regulation Act 1980.

During late 1990s, the dimensions of purse seine gear used ranged from $600 \times 50$ to $750 \times 65 \mathrm{~m}$ and the mesh size varied from 18 to $30 \mathrm{~mm}$, depending on the target species. Main body of the netting was fabricated with polyamide (PA) $210 \mathrm{~d} / 1 / 2$ and bunt area with PA $210 \mathrm{~d} / 2 / 3$. The selvedges were made of polyethylene (PE) netting with $28 \mathrm{~mm}$ mesh size. Head rope of $12 \mathrm{~mm}$ dia polypropylene (PP) ropes and foot rope of PE having slightly less diameter than head rope $(10 \mathrm{~mm})$ were in use. Design details of a typical purse seine gear of $750 \mathrm{~m}$ hung length operated off Cochin during 1990s, are given in the Fig. 1.

Modern equipment such as net haulers and acoustic fish detection equipment were not used in the small-scale mechanised purse seiners, during this period. The crew onboard included serang, engine driver, crew member responsible for the detection of fish shoals and for giving guidance on the direction of approach and timing of the encircling operation, cook and sufficient number of deckhands.

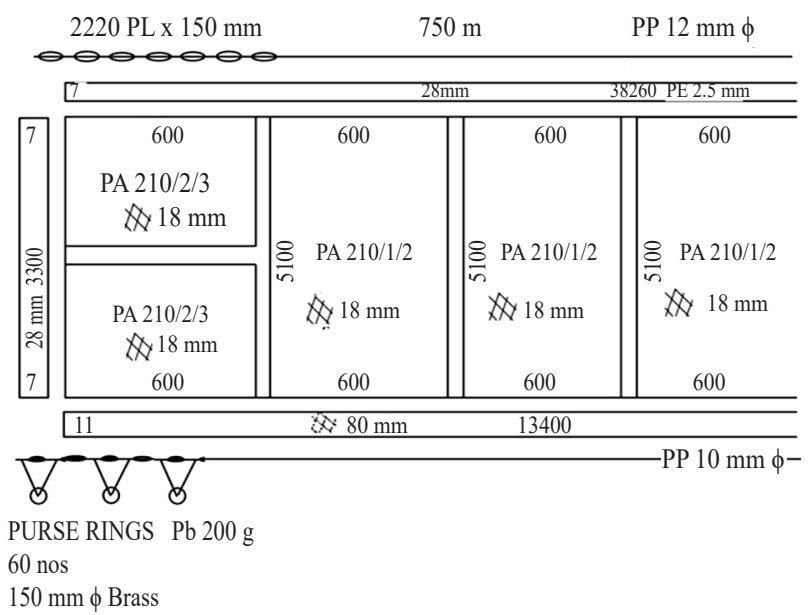

Fig. 1. Design details of a purse seine of (750 m hung length) operated off Cochin, during 1990s
The number of trips made by various length classes of purse seiners ranged from 8 to 24 trips per month (Fig. 2). The total running time of engine is taken as the sum of cruising time, searching time and fishing time. The running time of engine in purse seiners varied on an average from 75 to $280 \mathrm{~h}$ per month among the selected length classes (Fig. 3). The time taken to reach the prospective fishing ground varied with the season and the monthly average cruising time expended by different length classes of purse seiners ranged from 12 to 140 h (Fig. 4).

Once the vessel reaches the prospective fishing ground, it starts searching for a shoal of right size of targeted species for encircling and the average search time on a trip varied from 2 to $5.5 \mathrm{~h}$. The average monthwise search time among the purse seiners varied from

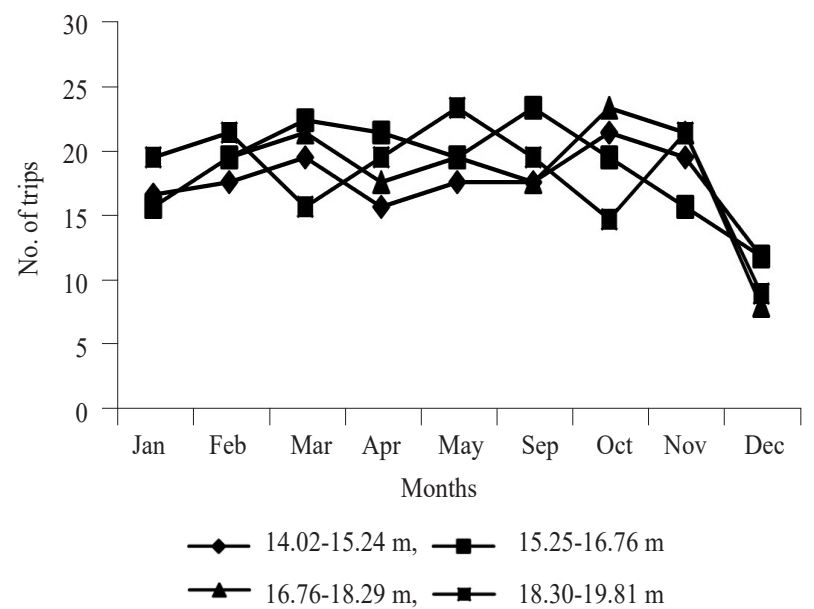

Fig. 2. Month-wise average number of trips made by different length classes of purse seiners during January to December 1997

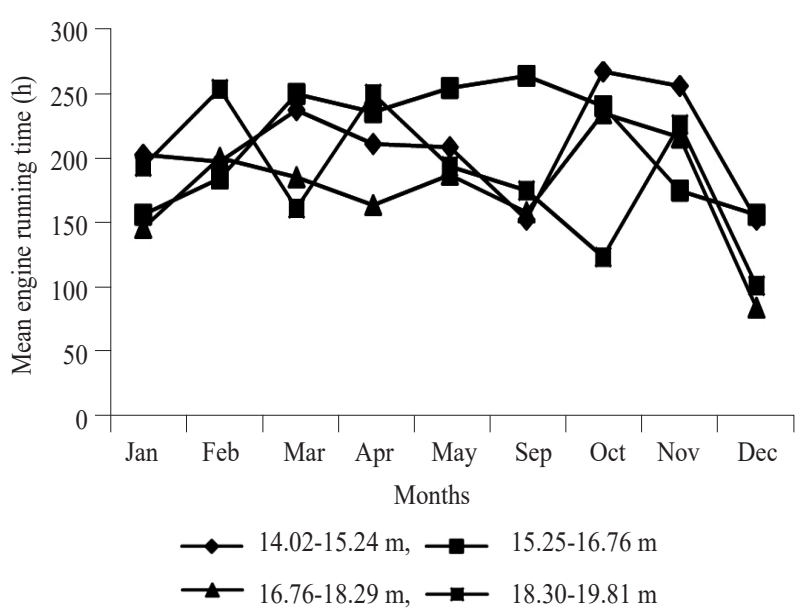

Fig. 3. Month-wise mean engine running time by different length classes of purse seiners 


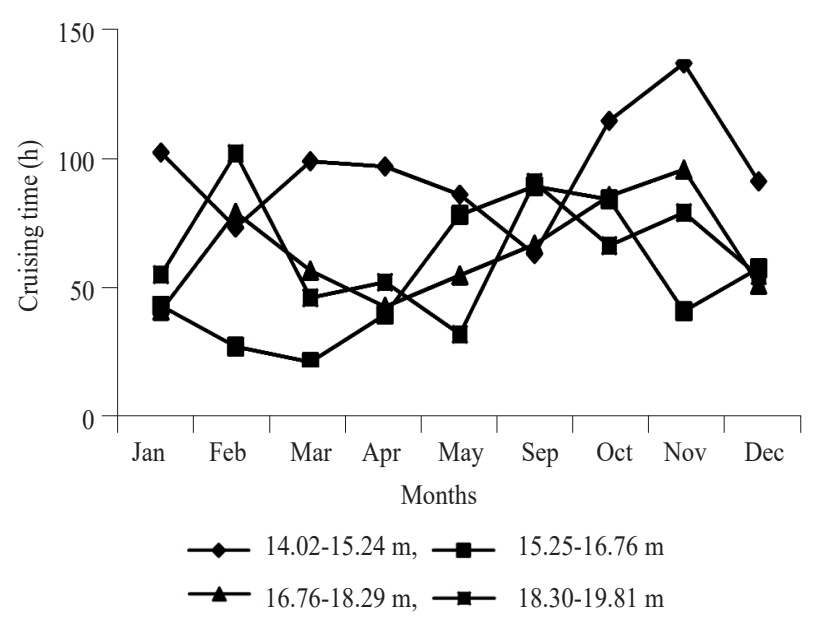

Fig. 4. Month-wise mean cruising time in different length classes of purse seiners

30 to $150 \mathrm{~h}$ (Fig. 5). The search time was low during the immediate post and pre-monsoon months, due to relative abundance of shoals. The detection of shoal was done by the fishermen with their traditional knowledge and experience. The hydro-acoustic devices such as sonar were not popular among purse seine fishers during 1990s.

Even though purse seining is highly efficient, the frequency of success depends on the encounter of fishable shoals (Misund, 1989). Information on position and extent of fish concentrations, average size of shoal and depth and general movement of schools are vital for achieving efficiency in purse seine operations (Pravin, 2009). The shooting operations will commence only if the size of the shoal and species justify the economy of operation. Purse seining is usually conducted when the concentration of a shoal is approximately between the densities of

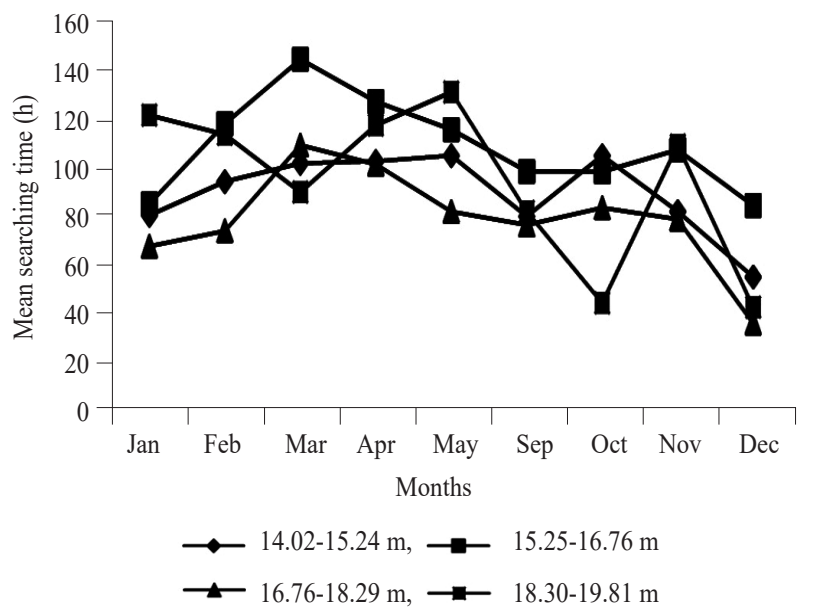

Fig. 5. Month-wise mean search time in different length classes of purse seiners
0.5-5.0 $\mathrm{kg} \mathrm{m}^{-3}$ (Fridman, 1986). Actual fishing time is the time taken from setting to hauling the net onboard the vessel, after the successful encircling of the shoal. On an average, the fishing time for different months among purse seiners varied from 10 to $100 \mathrm{~h}$ (Fig. 6). It showed that probability of encountering the shoals were inconsistent as none of the seiners operated along Cochin coast were having fish finding devices onboard during 1990s (Shibu, 1999). The actual fishing time was only about 24 to $33 \%$ of the total running time of engine in purse seiners among different length classes and considerable running time has been spent for searching and cruising. The least percentage of fishing time to total running time of engine was observed in smaller length class of purse seiners (14.02-15.24 $\left.\mathrm{m} \mathrm{L}_{\mathrm{OA}}\right)$. The fishing time formed $33 \%$ of total running time of engine among larger vessels of 18.30-19.81 $\mathrm{m} \mathrm{L}_{\mathrm{OA}}$, probably due to greater time requirements for handling the large gear.

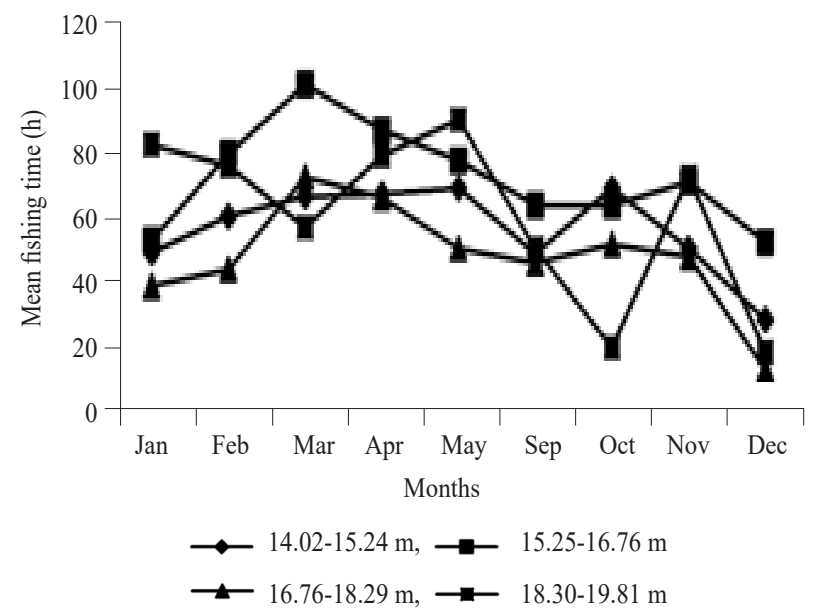

Fig. 6. Month-wise mean search time in different length classes of purse seiners

The study conducted during late 1990s, indicated that considerable amount of time has been spent for detection of shoal due to the lack of any fish finding equipment onboard, which in turn resulted in wastage of fuel. Significant improvements in operational efficiency could be possible through adoption of suitable measures like installation of sonar and use of potential fishing zone (PFZ) information in conjunction with global position system (GPS) and use of fish aggregating devices (FADs). The use of FAD for reducing the search time and thereby fuel consumption is popular in several purse seine fisheries (Ben-Yami, 1994; Ibrahim et al., 1994; Hameed and Boopendranath, 2000; Pravin, 2009). High cost of fish finding devices like sonar is a major challenge for small-scale mechanised purse seine operators, hindering its adoption. 
Purse seine fishing was first introduced in India, off Quilon in 1954 (Mukundan and Hakkim, 1980) and off Goa during 1957-58 (Sadanandan et al., 1975). Intensive and systematic purse seining was experimentally started as part of the Indo-Norwegian Project (INP) for exploiting pelagic fishery resources from the southern coast of India (Menon, 1970). The purse seines which measured $320 \mathrm{~m}$ in length and 20-28 $\mathrm{m}$ in hung depth, were operated from $11 \mathrm{~m} \mathrm{~L}_{\mathrm{OA}}$ vessels. The gear was made up of polyamide knotless webbing, with a thick twined bunt at one end. The head rope and foot rope were made of polyethylene ropes of $320 \mathrm{~m}$ and $330 \mathrm{~m}$ in length, respectively and the purse line was about $500 \mathrm{~m}$ in length (Balan, 1973).

Purse seine fishing operations started in Cochin area during the latter half of 1979 with about 10 units, which increased to about 40 and 60 in 1980 and 1981, respectively. Large fleets of purse seiners, constituting about 200 vessels in Karnataka and 60 vessels in Kerala in a matter of 2-3 years have created considerable management issues (Silas et al., 1980). During the period 1980-81, the fishing vessels used for purse seine operation were of $13 \mathrm{~m} \mathrm{~L}_{\mathrm{OA}}$ and gear used were of $500-600 \mathrm{~m}$ in length and 50-60 $\mathrm{m}$ in hung depth and mesh sizes in the main body ranged from 13 to $20 \mathrm{~mm}$ (Jacob, 1982). ICAR-Central Institute of Fisheries Technology (ICAR-CIFT), Cochin designed and developed a mini-purse seine (ring seine) with an overall dimension of $250 \times 33 \mathrm{~m}$, fabricated with knotless netting of $18 \mathrm{~mm}$ mesh size, during 1982-83, for operation from traditional motorised craft (thangu vallom) (Panicker et al., 1985). Recent developments in purse seine fisheries in India have been discussed by Pravin (2009), Meenakumari et al. (2010), Gopal and Edwin (2013), Edwin et al. (2014a,b) and Pravin and Meenakumari (2016). Introduction of large mesh purse seine, in order to reduce catch of juveniles and also to target large pelagic fishes and introduction of power block which makes the hauling of the net with minimum man-power, facilitated by ICAR-CIFT were significant developments in recent times.
During the early years of introduction of purse seining, the vessel sizes ranged from 12 to $13 \mathrm{~m} \mathrm{~L}_{\mathrm{OA}}$ (Balan, 1973; Mukundan et al., 1980; Mukundan and Hakkim, 1980). During late 1990s, vessels up to $20 \mathrm{~m} \mathrm{~L}_{\text {OA }}$ with engine power ranging up to $272 \mathrm{hp}$ were introduced in the fleet (Shibu, 1999; Boopendranath, 2000). The structural changes in terms of size and installed engine power of purse seiners of Kerala in later years up to 2012 have been discussed by Renju et al. (2014). The upper size limit of purse seiners reached $22 \mathrm{~m} \mathrm{~L}_{\mathrm{OA}}$ in recent times and the engine horsepower of the vessel escalated up to 400-510 hp (Renju et al., 2014). The most significant change in the purse seiners operated off Cochin, is the upward trend in the engine horsepower, coinciding with increase in size of the purse seines deployed (Edwin et al., 2014a,b; Renju et al., 2014). Edwin et al. (2014a) conducted a survey on mechanised craft and gears of marine fisheries of Kerala during the period 2012-13 and reported that the size of purse seiners ranged from 14 to $23 \mathrm{~m} \mathrm{~L}_{\mathrm{OA}}$ and the installed engine power ranged from 198 to $440 \mathrm{hp}$. Information gathered under the present study, from purse seine operators of Cochin and Munambam harbours, Kerala, during 2008-2015, showed that the vessel size ranged up to $22 \mathrm{~m} \mathrm{~L}_{\mathrm{OA}}$ and engine horsepower up to $510 \mathrm{hp}$.

Since its introduction in Indian waters, several changes and improvements have taken place in the design and operation of purse seines. With the upward changes in the size and horsepower of the purse seine vessels, the dimensions of the gear have also increased as evident from Table 1 (Balan, 1973; Mukundan et al., 1980; Mukundan and Hakkim, 1980; Jacob et al., 1982; Shibu, 1999; Boopendranath, 2000; Edwin et al., 2014a,b). The dimensions of the gear which was about $320 \times 28 \mathrm{~m}$ during early $1970 \mathrm{~s}$, increased to $600 \times 60 \mathrm{~m}$ during early $1980 \mathrm{~s}$, $823 \times 73 \mathrm{~m}$ during late $1990 \mathrm{~s}$ and further to $1200 \times 100$ $\mathrm{m}$ towards 2015. Mesh sizes used in the main body of the seine which was $12-13 \mathrm{~mm}$ during the early days of introduction of the gear, increased to $20-46 \mathrm{~mm}$ in recent years. A study has been conducted by Rao (2010) to

Table 1. Changes in purse seine craft and gear in Indian fisheries, during 1968-2015

\begin{tabular}{|c|c|c|c|c|c|}
\hline \multirow[t]{2}{*}{ Period } & \multicolumn{2}{|c|}{ Dimensions } & \multirow{2}{*}{$\begin{array}{l}\text { Mesh size of the } \\
\text { main body (mm) }\end{array}$} & \multirow{2}{*}{$\begin{array}{l}\mathrm{L}_{\mathrm{OA}} \text { of the fishing } \\
\text { craft }(\mathrm{m})\end{array}$} & \multirow[t]{2}{*}{ Source } \\
\hline & Head rope length $(\mathrm{m})$ & Depth (m) & & & \\
\hline $1968-1971$ & 320 & $20-28$ & $12-13$ & 11.0 & Balan (1973) \\
\hline 1980 & 400 & 55 & - & $13.2-15.0$ & $\begin{array}{l}\text { Mukundan et al. (1980); } \\
\text { Mukundan and Hakkim (1980) }\end{array}$ \\
\hline $1980-1981$ & $500-600$ & $50-60$ & $12-20$ & 13.0 & Jacob et al. (1982) \\
\hline 1997 & 750 & 60 & $20-22$ & $14.0-20.0$ & Shibu (1999) \\
\hline $1997-1998$ & $768-823$ & $65-73$ & 22 & $13.7-19.8$ & Boopendranath (2000) \\
\hline $2012-2013$ & $600-1200$ & $60-100$ & $18-46$ & $14.0-23.0$ & Edwin et al. $(2014 \mathrm{a}, \mathrm{b})$ \\
\hline $2008-2015$ & $700-1200$ & $60-100$ & $20-46$ & $13.0-22.0$ & Present Study \\
\hline
\end{tabular}


reduce the juvenile and sub-adult fish caches in the purse seine fishery. The change-over from the conventional 20 to $45 \mathrm{~mm}$ mesh size led to the landing of larger size classes of high value pelagic species (Meenakumari et al., 2010).

Size of the vessel, installed engine power and dimensions of the gear increased over the years, which is obviously reflected in the fishing capacity. Excess fishing capacity will affect the sustainability of the fishery and hence needs to be regulated. Baiju et al. (2012) and Baiju and Boopendranath (2014) have recommended the need for standardisation of vessel capacities and regulation of allowable engine power for different length classes of purse seiners with a limit up to $190 \mathrm{hp}$ for vessels up to $15 \mathrm{~m} \mathrm{~L}_{\mathrm{OA}}$ and $240 \mathrm{hp}$ for vessels in the class of $15-20 \mathrm{~m} \mathrm{~L}_{\mathrm{OA}}$. Lack of skill among fishermen to correlate the technical data from fish finding devices, PFZ information and fishery environmental data are other impediments to realise operational efficiency, which require intervention through capacity building and skill development programmes.

\section{Acknowledgements}

The authors are thankful to the Director, School of Industrial Fisheries, Cochin University of Science and Technology (CUSAT) for providing the necessary facilities. The support extended by the Director, Central Institute Fisheries Nautical and Engineering Training (CIFNET), is thankfully acknowledged and we would like to express our sincere gratitude to Dr. M. R Boopendranath, former Principal Scientist, ICAR-CIFT, Kochi for his valuable comments and suggestions.

\section{References}

Baiju, M. V. and Boopendranath, M. R. 2014. Estimation of optimum engine power of fishing craft with reference to length. Fish. Technol., 51(1): 67-69.

Baiju, M. V., Boopendranath, M. R. and Edwin, L. 2012. Need for regulating horsepower in small scale mechanised fishing vessels. Fisheries Policy Update, Central Institute of Fisheries Technology (CIFT), Kochi.

Balan, V. 1973. Purse seine and boat seine (Thangu vala) fishery for the oilsardine off Cochin, 1968-71. Indian J. Fish., 20(1): 70-77.

Ben-Yami, M. 1994. Purse seining manual, FAO Fishing manual, Fishing News Books Ltd., Farnham, 416 pp.

Boopendranath, M. R. 2000. Studies on energy requirement and conservation of selected fish harvesting systems. Ph.D. Thesis. Cochin University of Science and Technology, Cochin, India, 273 pp.

CMFRI 2012. Marine fisheries census 2010 Part-I India, Department of Animal Husbandry, Dairying and Fisheries and Central Marine Fisheries Research Institute, Cochin, $98 \mathrm{pp}$.

Edwin, L., Pravin, P., Madhu, V. R., Thomas, S. N., Remesan, M. P., Baiju, M. V., Ravi, R., Das, D. P. H., Boopendranath, M. R. and Meenakumari, B. 2014a. Mechanised marine fishing systems: India. Central Institute of Fisheries Technology, Kochi, 277 pp.

Edwin, L., Thomas, S. N., Pravin, P., Remesan, M. P., Madhu, V. R., Biju, M. V., Sreejith, P. T., Ravi, R. and Das, D. P. H. 2014b. CIFT fishing system catalogue 1 - Mechanised marine fishing systems: Kerala. Central Institute of Fisheries Technology, Kochi, 113 pp.

Fridman, A. L. 1986. Calculations for fishing gear designs, FAO Fishing Manual, Fishing News Books, Oxford, 241 pp.

Gopal, T. K. S. and Edwin, L. 2013. Development of fishing industry in India. J. Aquat. Biol. Fish., 1(1\&2): 38-53.

Hameed, M. S. and Boopendranath, M. R. 2000. Modern fishing gear technology, Daya Publishing House, Delhi, 180 pp.

Ibrahim, S., Mohd, I. M. and Ambak, M. A. 1994. Purse seining with FADs in Malaysia. Infofish International, 4(94): 69-72.

Jacob, T., Alagaraja, K., Dharmaraja, S. K., Panikkar, K. K. P., Balakrishnan. G., Satyawan, U. K., Balan V. and Rao K. V. N. 1982. Impact of purse seine operations on traditional fishery with special reference to oilsardine in Kerala during 1980 and 1981. Mar. Fish. Inf. Serv. T\&E Ser., No. 40: 8-11.

Meenakumari, B., Pravin, P. and Nikita Gopal 2010. Improved large mesh purse seine for small-scale mechanised sector. In: Meenakumari, B., Boopendranath, M. R., Edwin, L., Sankar, T. V., Gopal, N. and Ninan, G. (Eds.), Coastal fishery resources of India: Conservation and sustainable utilisation, Society of Fisheries Technologists (India), Cochin, p. 294-304.

Menon, M. D. 1970. Purse seining oil sardines from medium vessels. Souvenir. Central Institute of Fisheries Operatives, Kochi, p. 28-31.

Misund, O. A. 1989. Swimming behaviour of herring (Clupea harengus L.) and mackerel (Scomber scombrus L.) in purse seine capture situations. In: Fox, S. G. and Julie, H (Eds.), Proceedings of the World Symposium on Fishing gear and fishing vessel design, November 1988, Marine Institute, St John's, Newfoundland, Canada, p. 541-546.

Mukundan, M. and Hakkim, L. A. 1980. Purse seining development in Indian waters, Bulletin No. 3, Integrated Fisheries Project. Ministry of Agriculture, Government of India, $59 \mathrm{pp}$.

Oommen, V. P. 1989. A critical study on the exploitation of fishery resources by the Integrated Fisheries Project, Bull. No. 12, Integrated Fisheries Project, Ministry of Agriculture, Government of India, $106 \mathrm{pp}$. 
Panicker, P. A., Sivan, T. M. and George, N. A. 1985. A new fishing gear for traditional craft, In: Ravindran, K., Nair, N. U. K., Perigreen, P. A., Madhavan, P., Pillai, A. G. G. K., Panicker, P. A. and Thomas, M. (Eds.), Harvest and post harvest technology of fish, Society of Fisheries Technologists (India), Cochin, p. 223-226.

Pravin, P. 2009. Purse seines and their operation, In: Meenakumari, B., Boopendranath, M. R., Pravin, P., Thomas, S. N. and Edwin, L. (Eds.) Handbook of fishing technology, Central Institute of Fisheries Technology, Cochin, p. 177-194.

Pravin, P. and Meenakumari, B. 2016. Purse seining in India - a review. Indian J. Fish., 63(3): 162-174.

Rao, G. S. 2010. Current status and prospects of fishery resources of the Indian continental shelf, In: Meenakumari, B., Boopendranath, M. R., Edwin, L., Sankar, T. V., Gopal, N. and Ninan, G. (Eds.), Coastal fishery resources of India: Conservation and sustainable utilisation, Society of Fisheries Technologists (India), Cochin, p. 1-13.

Renju R., Vipin P. M., Boopendranath, M. R., Joshy, C. G. and Leela Edwin 2014. Structural changes in the mechanised fishing fleet of Kerala, South India. Indian J. Fish., 61(2): $1-6$

Sadanandan, K. A., Kunjipalu, K. K., George, N. A. and Joseph Mathai, T. 1975. Purse seines off Goa. Fish. Technol., 12(1): 45-51.

Shibu, A. V. 1999. Comparative efficiency of different types of mechanised fishing operations along the Cochin coast, $\mathrm{Ph}$. D. Thesis, Cochin University of Science and Technology, $217 \mathrm{pp}$.

Silas, E. G., Pillai, P. P., Dhulkhed, M. H., Muthiah, C. and Syda Rao, G. 1980. Purse seine fishery - Imperative need for regulation. Mar. Fish Infor. Ser. T\& E Ser, 24: 1-9. 